\title{
AN INVESTIGATION INTO A CONVENTIONAL SPINNING PROCESS COMBINED WITH FLOW FORMING WITH SIMULTANEOUSLY BURNISHING PROCESSES
}

\author{
K. M. Atia*1 ${ }^{1}$ S. Z. El-Abden ${ }^{2}$, M. N. El-Sheikh ${ }^{3}$ and W. W. Marzouk ${ }^{4}$ \\ ${ }^{1,2,4}$ Production Engineering and Mechanical Design Department, Minia university, Minia, Egypt \\ ${ }^{3}$ Mechanical Engineering Department, Beni-Suef University, Beni-Suef, Egypt. \\ *Corresponding Author E-mail: karim.m.atia@mu.edu.eg
}

\begin{abstract}
Spinning process is a sheet metal forming technology used in the production of the symmetrical industrial parts. It is an efficient and inexpensive manufacturing process and has been widely used in various applications. In this research, new technique was developed to perform three different operations in the same stroke, namely conventional spinning, shear spinning (wall thickness reduction) and burnishing processes. This new technique has been performed by a new tool which consists of three stages, the first stage consists of two rollers to carry out conventional spinning process; the second stage includes two opposite balls to perform the process of shear spinning and the last stage comprises another two opposite balls to perform the process of burnishing. The burnishing balls differ from the shear balls in which that the burnishing balls have a spring behind the balls to decide the required burnishing load. Experimental work was conducted and confirmed the success of the presented technique. The response of the product quality and required load to process parameters such as rotational speed $(46,76,150$ and $230 \mathrm{rpm})$, axial feed $(0.15,0.3,0.6$ and $1.21 \mathrm{~mm} / \mathrm{rev})$ and burnishing load $(20,25$ and $30 \mathrm{KN}$ ) was checked and clarified. The results showed that, the optimum condition for forming load occurred at rotation speed at $150 \mathrm{rpm}$, axial feed $0.3 \mathrm{rev} / \mathrm{mm}$ and burnishing load $25 \mathrm{KN}$.
\end{abstract}

Keywords: Combined Processes, Conventional Spinning, Shear Flow Forming, Ball Burnishing.

\section{INTRODUCTION}

In sheet metal forming, a sheet blank is deformed, normally, into a threedimensional object. The deformation usually changes the shape of the part. The surface area-to-volume ratio of the starting metal is high; thus, this ratio is a useful means to distinguish bulk deformation from sheet metal processes [1]. Sheet metal operations are always performed as cold working processes and are usually accomplished using a set of tools called a punch and die.

The commercial importance of sheet metal working is significant. Consider the Received:1 Februaryl, 2020, Accepted: 27 February, 2020 number of consumer and industrial products that include sheet or plate metal parts: automobile and truck bodies, airplanes, railway cars, locomotives, farm and construction equipment, appliances, office furniture, and more. Although these examples are conspicuous because they have sheet metal exteriors, many of their internal components are also made of sheet or plate stock. Sheet metal parts are generally characterized by high strength, good dimensional accuracy, good surface finish, and relatively low cost $[2,3]$. 
Metal spinning refers to a group of forming processes that allow production of hollow, axially symmetric sheet metal components. The basic technique of spinning, which is common to this group of processes, consists of clamping a sheet metal blank against a mandrel on a spinning lathe, and gradually forming the blank onto the mandrel surface by a roller, either in a single step or series of steps $[4,5]$.

Components produced by spinning include parts for the automotive and aerospace industries, art objects, musical instruments and kitchen ware. Some typical examples are components for jet engines and turbines, radar reflectors, satellite nose cones as well as cymbals and domestic utensils. The process is capable of forming components of diameters ranging from $3 \mathrm{~mm}$ to $10 \mathrm{~m}$, and thicknesses of $0.4-25 \mathrm{~mm}$ [6].

The term metal spinning refers to a group of three processes: conventional spinning, shear spinning and tube spinning. A common feature of the three processes is that they allow production of hollow, rotationally symmetric parts. The main difference between the three is apparent in the wall thickness of the formed part [7].

In conventional spinning, the wall thickness remains nearly constant throughout the process, so the final wall thickness of the formed part is equal to the thickness of the blank. In contrast, the wall thickness is reduced in shear spinning and tube spinning; in shear spinning, part thickness is dictated by the angle between the wall of the component and the axis of rotation; in tube spinning, the final thickness is defined by the increase in length of the workpiece. Furthermore, while in conventional spinning and tube spinning parts can be formed in a single step or several steps, in shear spinning, forming is done in a single step [8].

Surface modifications as well as surface treatments play important role to enhance service life of many critical parts of different materials that are used for engineering applications. Burnishing is a surface finishing process which leads to change in the surface roughness of the work piece by a considerable amount of plastic deformation. Along with producing a good surface finish, the burnishing process leads to improvement in hardness, fatigue life and corrosion resistance as result of induced compressive residual stress $[9,10]$. Surface quality is a significant parameter for evaluating engineering quality of parts. Burnishing process imposes cold working on the part surface due to movement and rearrangement of surface layers [11]. Burnishing process can be typically classified into two categories as roll burnishing and ball burnishing [12]. Ball burnishing is a surface finishing process performed by a sphere that rolls over the target surface while applying a controlled force. By effect of the exerted pressure, the peaks that define the surface texture are deformed, thus reducing the scale of its topological features [13]. The process is known for achieving a triple enhancing effect on the surface integrity of different materials: a decrease in surface roughness, an increase of the surface and subsurface layers hardness, and reinforcement of the compressive residual stress to a depth of nearly $1 \mathrm{~mm}$ [14]. Last two decades the research in metal spinning and its parameters were the point of interest. A lot of investigations pointed out that the sheet thickness and the blank diameter are the main influencing parameters on wrinkling. Xia et al. [15] showed that a small sheet thickness and a large blank diameter increase wrinkling during the spinning process. Furthermore, Özer et al. [16] conducted that the roller feed rate has a significant influence on the spinning result. It was shown experimentally that increasing the roller feed rate leads to a higher tendency to wrinkling. Additionally, Kalpakjian and Rajagopal [17] determined that wrinkling could be reduced by using a larger roller nose radius. The occurrence of circumferential cracks essentially depends on the blank diameter, the roller feed rate and the roller nose radius. Xia et al. [15] investigated the single-pass conventional spinning of cups made of aluminum and 
mild steel. It was shown that a larger initial blank diameter increases the risk of circumferential cracking. In addition, the influence of the roller feed rate on cracking was analyzed. As a result, it was determined that a small roller feed rate leads to a higher risk of cracking. Switzner and Henry [18] confirmed these results. Moreover, Music et al. [4] reported that the risk of cracking could be minimized by using a large roller nose radius.

The effects of the thickness of blank, mandrel, roller nose radius, rotation speeds, feed of the roller and over-roll thickness on the surface roughness of cone shape items was investigated by Chen et al. [19]. It was concluded that heavy over-roll combine with the thinner sheet blank, big roller nose radius and slower roller feed are useful for get smooth surface roughness. Over-roll of the blank in flow spinning is a successful way to decrease the surface roughness of the part.

However, Molladavoudi and Djavanroodi [20] Inspected the influence of thickness decrease on the mechanical properties and spinning accuracy on aluminum workpiece. The experimental results show that with increase of thickness reduction the yield strength, ultimate tensile strength, and surface hardness increase, and on the other hand, it has opposite effect on diameter increase, accuracy of the tube, surface roughness, and elongation of tube.

Burnishing process and its parameters are highly affecting the process of metal spinning. Therefore, Due to the fact that ball burnishing includes such a high amount of processing parameters (force, feed, lateral pass width, number of passes, ball diameter, rotation speed, original surface roughness and residual stress, lubrication, ball material, etc.), its study is often guided by applying experimental design techniques [14]. Different materials have been extensively studied during the last years. For instance, El-Tayeb et al. [21] proved the positive results of the process on Alloy Aluminum 6061 alloy, finding that burnishing speed of $330 \mathrm{rpm}$ and burnishing force of $212 \mathrm{~N}$ can improve surface roughness as much as $40 \%$. However, an increase in the roller contact width leads to less improvement in the surface roughness. Meanwhile, roller burnishing also enhance the hardness of burnished Aluminum Alloy 6061 by 20$30 \%$.

In the area using balls for flow forming spinning Abdel-twab et al [22] conducted a research on the ability of using balls to perform a reduction in a pipe wall thickness with inner rips creation, the proposed tool conducted the required wall thickness reduction and the inner rips too, Abdel-twab et al performed an examination into the effect of some process variables on the part quality and process required load, they reported the influence of mandrel rotational speed, feed rate, distances between balls, and the balls infeed on the product surface roughness and hardness beside the operation required load. Saied et al [23] suggested a new combined tool has the ability of performing conventional spinning with wall thickness reduction in one pass, they reported that the new proposed tool is successful in achieving the required cup with wall thinning in one pass.

The goal of this work is to design and manufacturing combined spinning tool. This tool capable of perform three different forming process simultaneously. these three processes are conventional spinning, flow spinning and burnishing process. as well as, study the influence of the process parameter like burnishing load, rotation speed, axial feed.

\section{EXPERIMENTAL WORK}

\subsection{New Combined Tool:}

The design of the tool for the proposed technique is shown in Figure (1). The tool consists of lathe chuck fitted with three different parts as follows:

(1) The two rollers performing the conventional spinning process. The assembly of the two rollers are mounted on two opposite jaws of separate lathe chuck with four independent jaws. The separate chuck service as a tool holder. This assembly makes the two rollers in the same 
level and the rollers are mounted on shafts with ball bearings to allow free rotation of the rollers to reduce friction during the forming process. The rollers can be moved inward or outward in radial direction of mandrel through the separate jaws of the chuck.

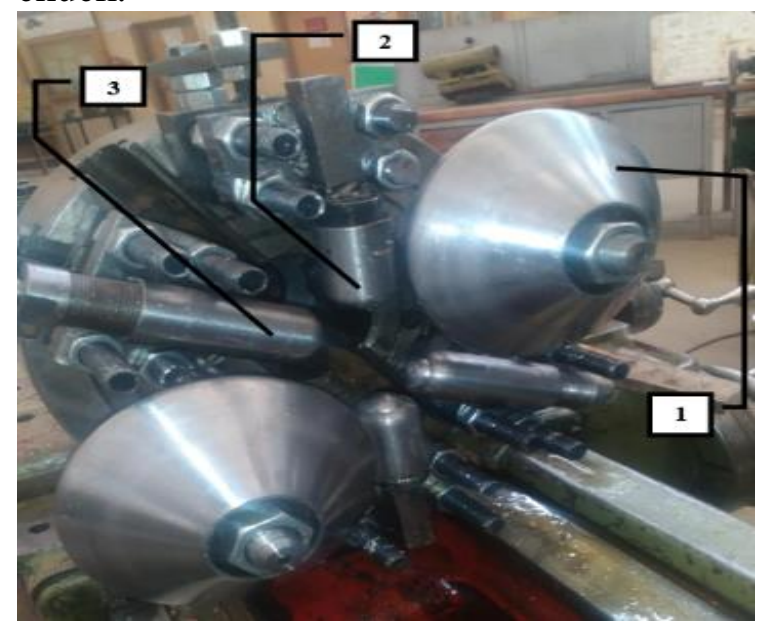

Fig.1. The completely new combined tool. (1) The rollers for conventional spinning (2) The balls for shear spinning (3) The balls for burnishing processes.

(2) The two balls which are performing the process of shear spinning have a diameter of $27 \mathrm{~mm}$. The balls are installed on new keyways in the chuck which have machined by milling machine. This assembly makes the two balls in the same level following the rollers level by about $10 \mathrm{~mm}$. The Mechanism allows the balls move inside and outside vertically on the mandrel axis.

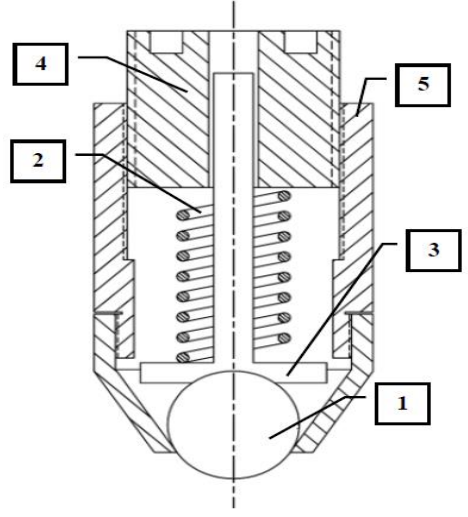

Fig.2. Schematic representation for burnishing housing. (1) ball $27 \mathrm{~mm}$ diameter (2) spring (3) pillar

(4) lock nut (5) burnishing tool housing.

(3) Two balls performing the burnishing process having the same diameter of shear balls. The two burnishing balls are mounted in the same way of balls of shear spinning process and have the same motion mechanism. Figures (2 and 3) show schematic representation for burnishing housing and the calibration curve for spring respectively. This spring used to perform the various burnishing loads on workpiece by turn the lock nut to compress the spring. That will lead to increases the ball load against the workpiece.

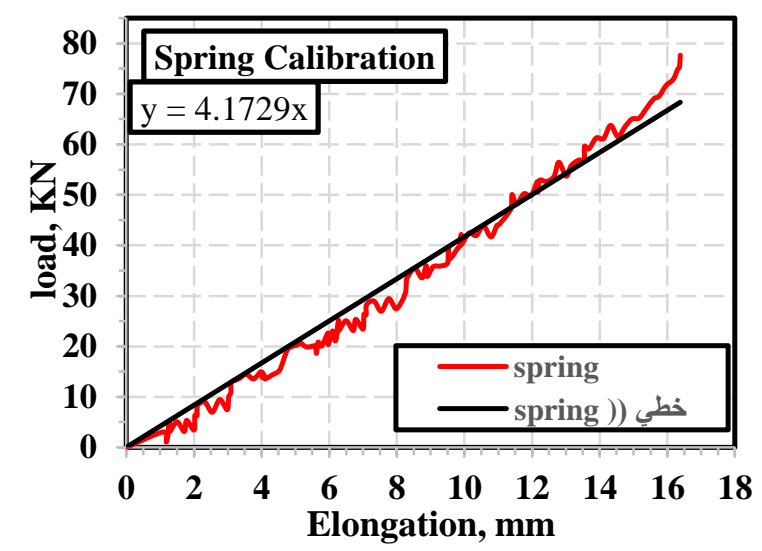

Fig.3. Spring calibration curve.

\subsection{Experimental Setup:}

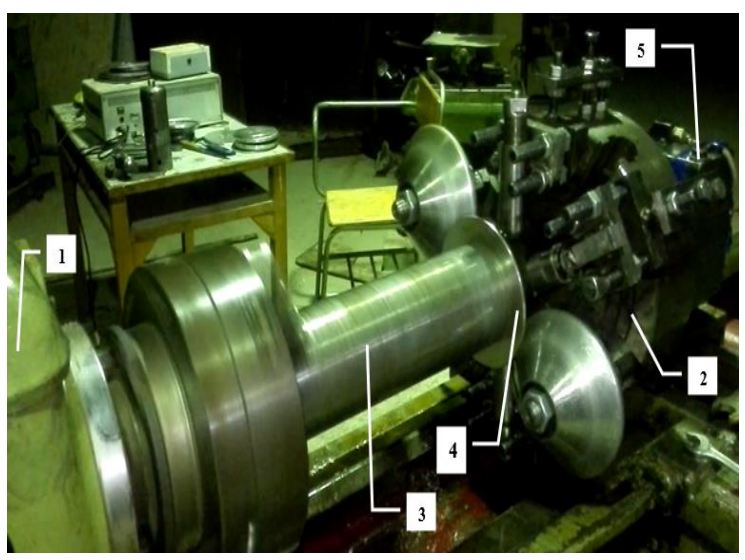

Fig.4. Experimental set-up of the combined process. (1) Center lathe machine (2) Combined new tool (3) Mandrel (4) Aluminum blank (5) Load measurement device.

The setup of the experimental work can be found in Figure (4). The apparatus consists of new tool (2) which is attached to the lathe carriage in order to use automatic feeding of carriage, the lathe machine (1), The mandrel with diameter of $105 \mathrm{~mm}$ (3) which is attached to the lathe chuck, and the 
blank (4) which is attached to the mandrel. The blank material was Aluminum as received with $155 \mathrm{~mm}$ diameter and the specimen was tested experimentally found to have yield strength of $66 \mathrm{MPa}$, strength coefficient of $141 \mathrm{MPa}$, and strain hardening exponent of 0.27 with $37 \mathrm{HV}$ Vickers hardness. It can be seen from Table (1) that the experimental variables have been examined.

Table 1. Experimental chosen parameters

\begin{tabular}{|l|l|}
\hline Material & $\begin{array}{l}\text { Aluminum Alloy } \\
6061\end{array}$ \\
\hline Mandrel speed (rpm) & $\begin{array}{l}46,76,150 \text { and } \\
230\end{array}$ \\
\hline Feed rate (mm/rev) & $\begin{array}{l}0.15,0.3,0.6 \text { and } \\
\end{array}$ \\
\hline Burnishing load (KN) & 20,25 and 30 \\
\hline Diameter of mandrel (mm) & 105 \\
\hline Initial blank Diameter (mm) & 155 \\
\hline Initial blank thickness (mm) & 3 \\
\hline Thickness of formed specimen & 1 \\
(mm) & 27 \\
\hline Balls diameter (mm) & \\
\hline
\end{tabular}

3. RESULTS AND DISCUSSIONS:

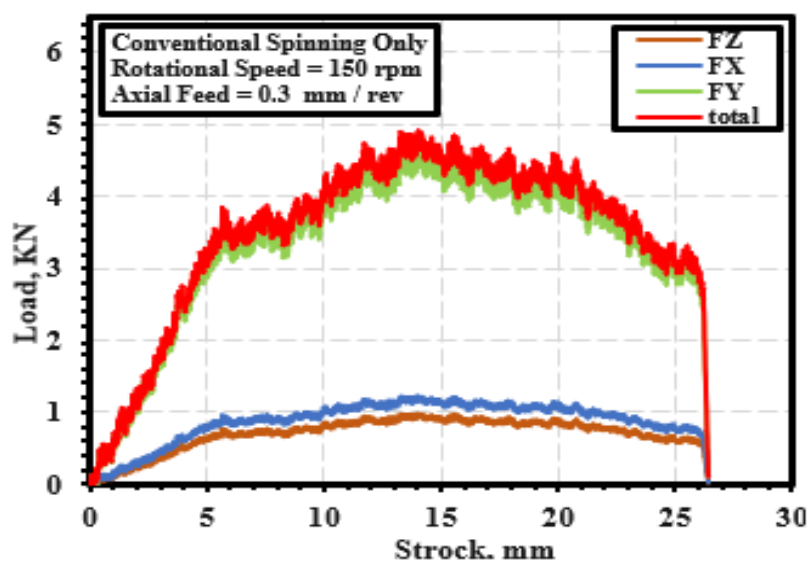

\subsection{Load-Displacement Curve of The Process.}

For the sake of compare the combined process (conventional spinning followed by flow forming for wall thickness reduction and burnishing process), a conventional spinning, flow forming process and burnishing process was performed one after another and the load displacement curve for the three process was monitored separately. Figure (5) shows the load displacement curve for conventional spinning, shear spinning and burnishing process in a same parameters of rotation speed and axial feed. Ever curve contains Fx, Fy and Fz. This mean that the load in radial, axial, tangential direction respectively.

In addition, the curve (Total) shown in Figure (6) is the calculation of these loads are given by:

$$
F_{T}=\sqrt{F_{X}^{2}+F_{Y}^{2}+F_{Z}^{2}}
$$

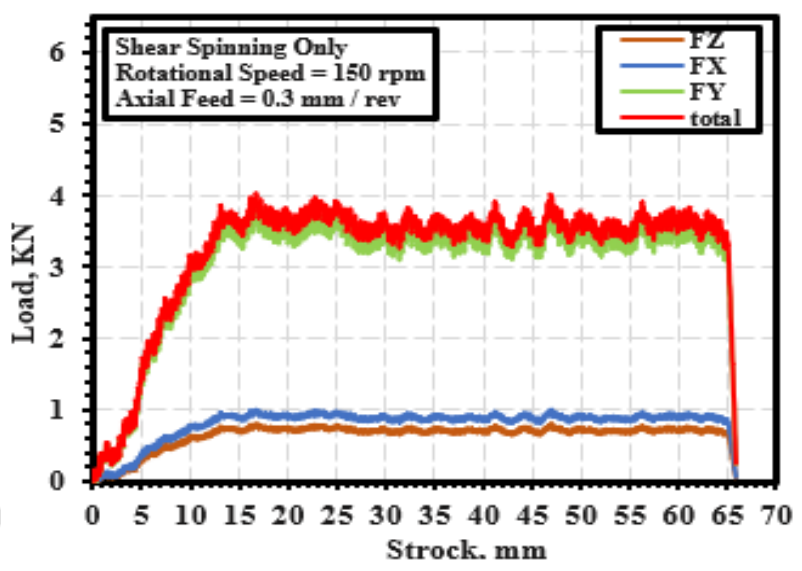

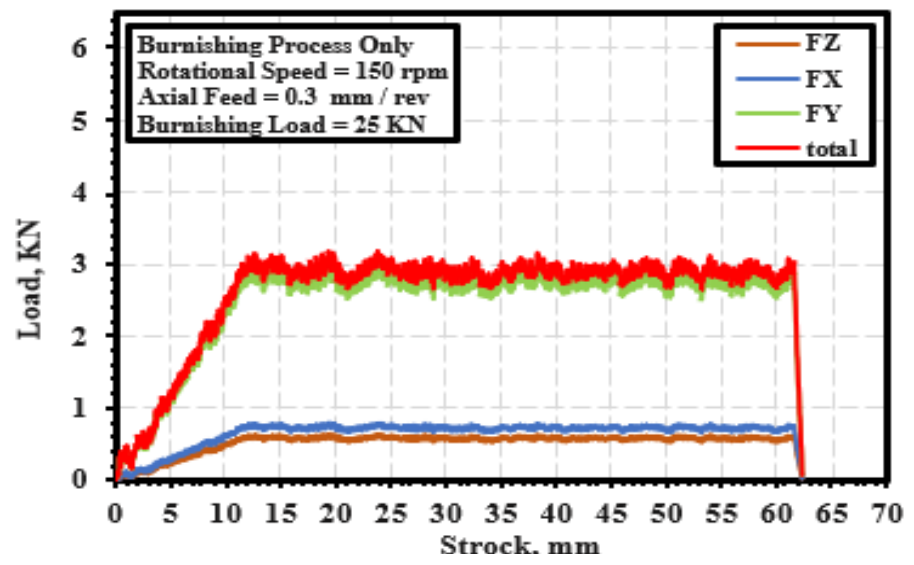

Fig.5. Load displacement curve for conventional spinning process, shear spinning process and burnishing process. 
The load displacement curve of the combined process is presented at Figure (6) for parameters of rotational speed of 150 rpm with axial feed ratio of $0.3 \mathrm{~mm} / \mathrm{rev}$ and $25 \mathrm{KN}$ of burnishing load.

And then, algebraic summation of the three processes are compared with combined proses on load displacement curve form (see
Figure (7)). One can observe that the total load of the combined process is less than the total algebraic summation of the three following processes by about 50\% which mean a reduction in the consumed power by the same ratio. The combined process also will greatly reduce the required time for producing the thin wall cup.

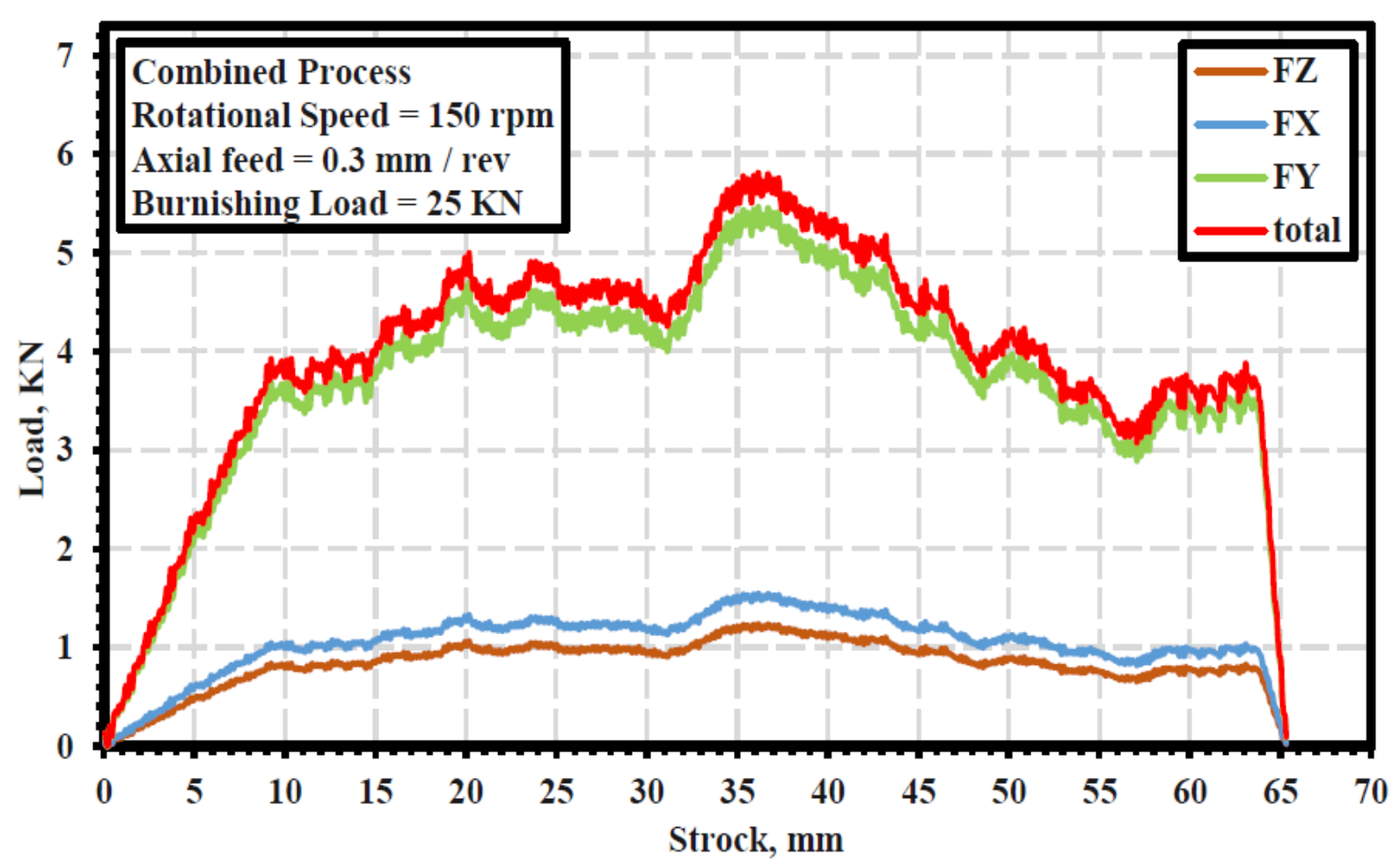

Fig.6. Load displacement curve for combined process.

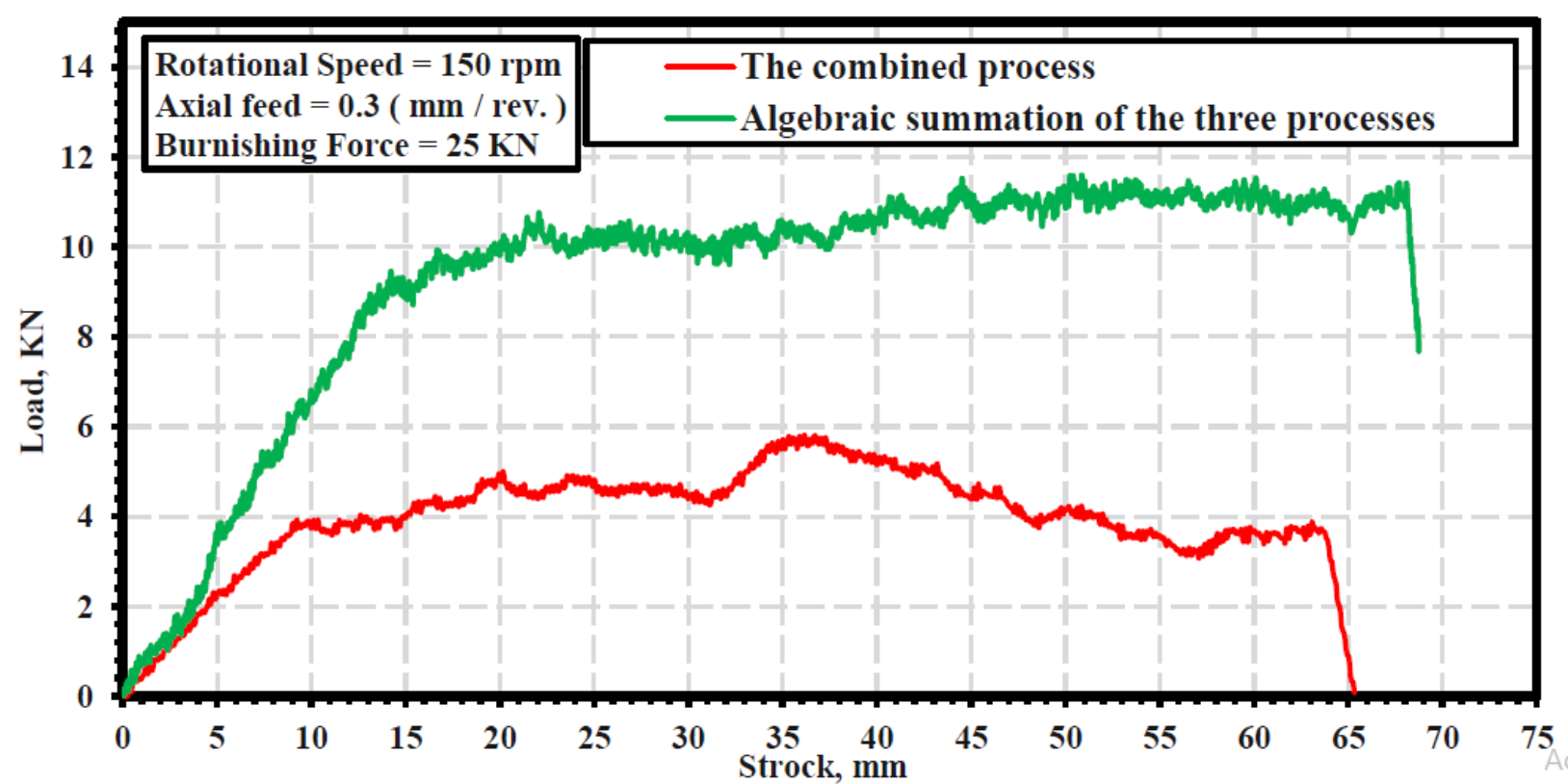

Fig.7. Comparison between the combined process and the algebraic summation of the three processes of conventional spinning, flow forming and burnishing process. 


\subsection{Effect on Maximum Total load:}

\subsubsection{Effects of the Axial Feed:}

The measured maximum forming total loads required for the combined process has been plotted versus the axial feed at different rotation speeds in Figure (8). It was found that the axial feed increasing decreases the maximum forming total load until it gets to its lowest level at the optimum axial feed of $0.3(\mathrm{~mm} / \mathrm{rev})$. This due to the agreement between this feed and the deformation rate of the material. The forming total load arises once more with the increase of the axial feed over its optimum value. This can be attributed to the increase in the strain hardening of the blank material in the forming operation. It can also be observed from Figure (8) that at the rotation speed of $150 \mathrm{rpm}$, the maximum deformation load is at its minimum value relative to other rotation speeds. These results extend in the three different burnishing loads.

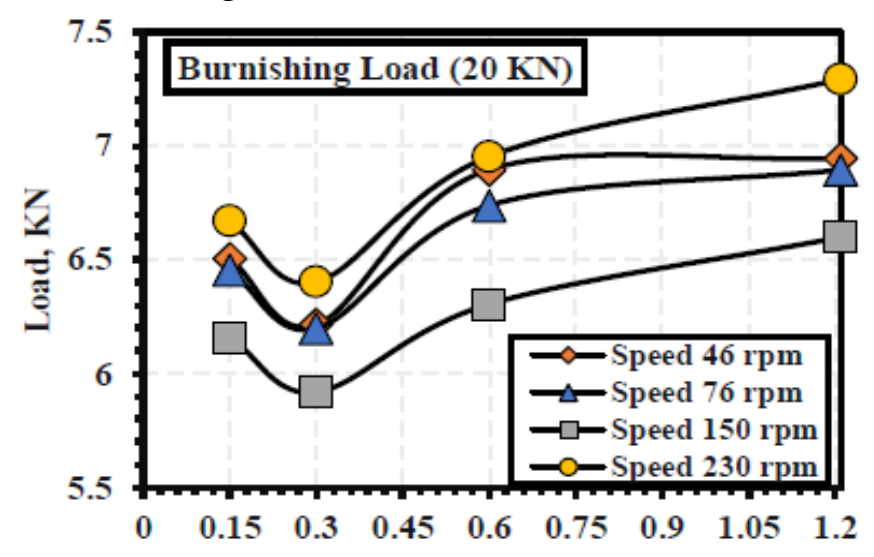

Axial Feed, mm/rev

\subsubsection{Effects of the Rotation Speed:}

The relations between rotation speed and maximum forming total load required for the proposed technique with various axial feeds can be found in Figure (9). It was noticed that the maximum deformation load decreases with the increase of rotation speed while it come to its minimum value at the optimum rotation speed of 150 (rpm). The curve of the forming total load attempted to arises again with any increase in the rotational speed. This conclusion can be found under burnishing load 20, 25 and $30(\mathrm{KN})$. It can be also found that in different burnishing load the axial feed 0.3 $(\mathrm{mm} / \mathrm{rev})$ has the lowest value compared with different axial feed.

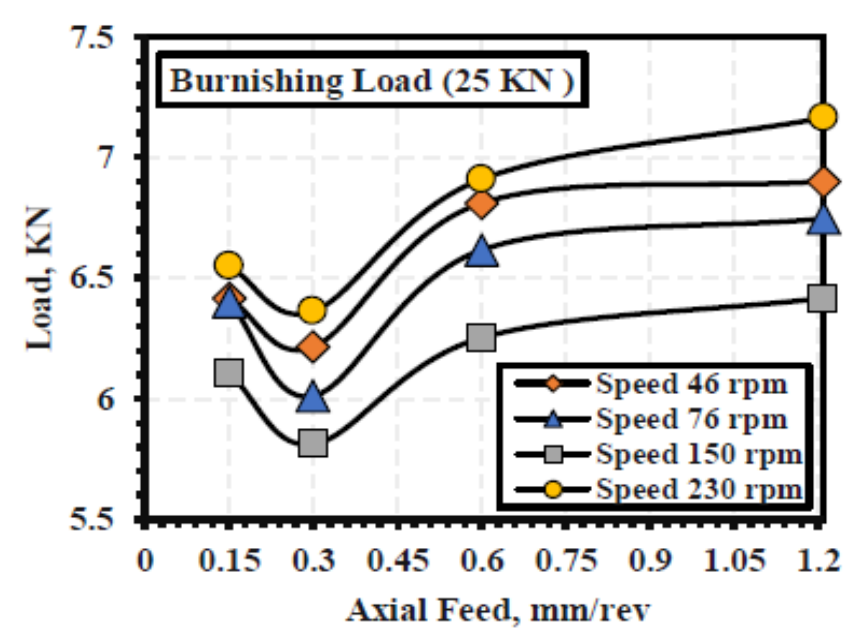

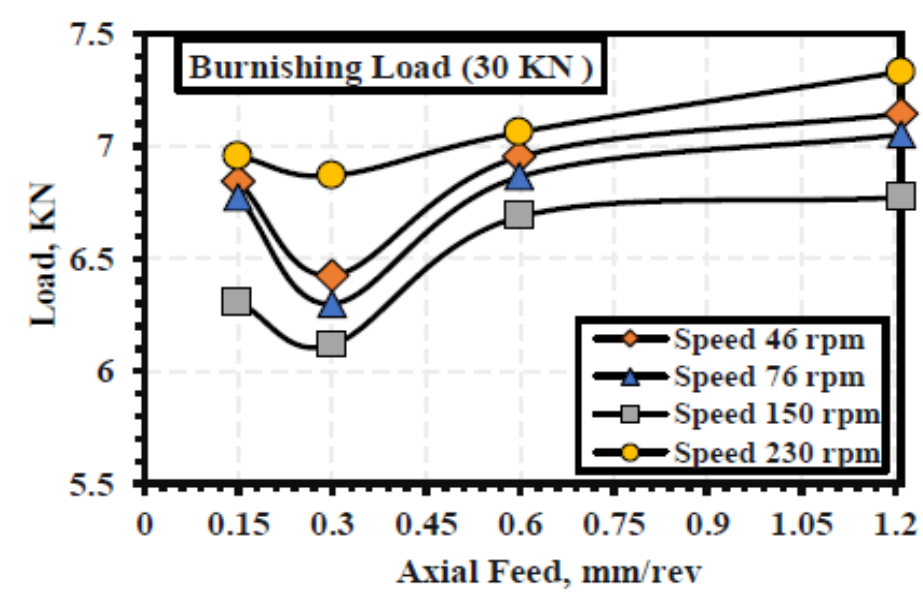

Fig.8. Relationships between maximum forming load and axial feed under. 


\section{Vol. 40, No. 1. January 2021}

different rotation speeds.
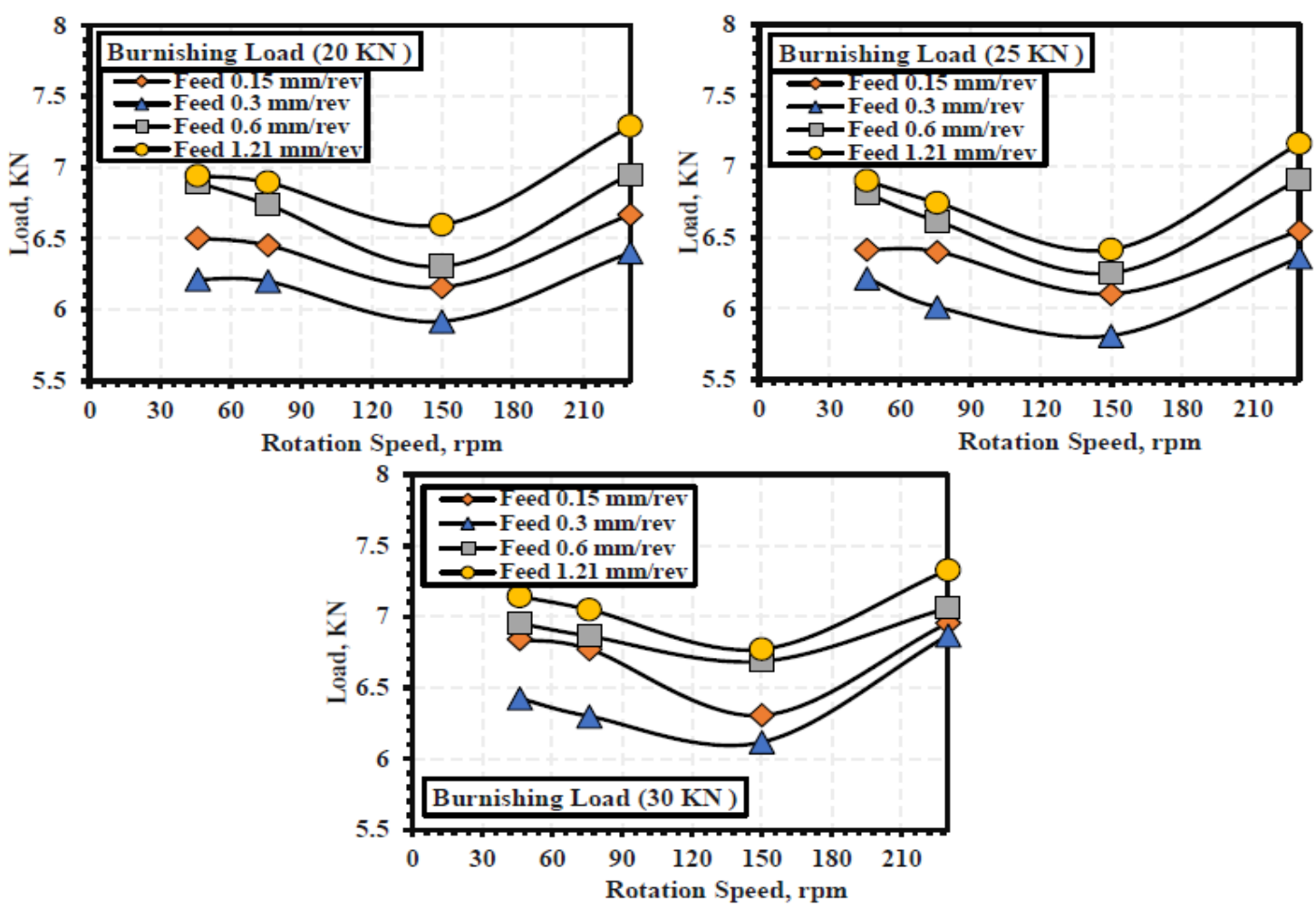

Fig.9. The relationships between maximum forming load and rotation speed with different axial feeds.
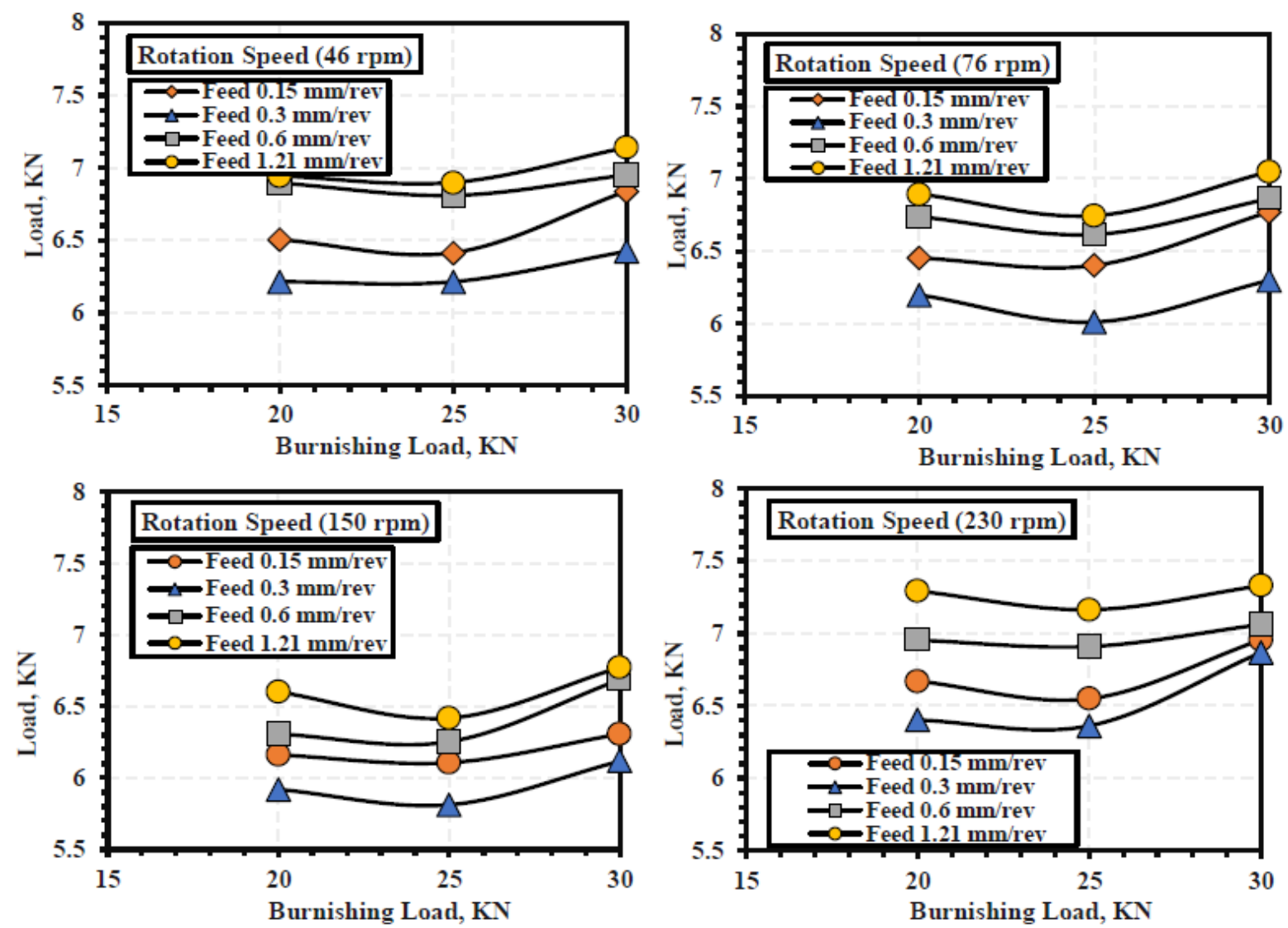

Fig.10. The relationships between maximum forming load and burnishing load under different axial feeds. 


\subsubsection{Effects of The Burnishing Load:}

The relationships between the burnishing load and the load required for the combined process are shown in Figure (10). It can be concluded from Figure (11) that, the increase in the burnishing load decreases the process load till $25 \mathrm{KN}$ burnishing load, then any increase in the burnishing load above $25 \mathrm{kN}$ increases the process load and this is mainly due to the increased plastic deformation with high burnishing loads.

\section{PHOTOGRAPH FOR THE SPECIMENS:}

Figure (11) illustrates the photograph of some successful cups that produced by the proposed new Technique.

Figure (12). shows the photograph of unsuccessful product. The defective products can be attributed to the high axial feed and disorder of toning in tool of the proposed technique (specimen 1 and 2). However, the defect observed in specimen 3 is probably explained by high burnishing load. Also, specimen 4, not succeeded because of high rotation speed. The tearing defect in specimen 5 can explained by intense penetration of shear balls due to increases of vibration.

\section{CONCLUSIONS:}

Under the conditions examined in the experimental work explained above, the following conclusions can be found:

1. The combined new tool which has been designed and manufactured to perform three different processes (conventional spinning, shear spinning and burnishing process) is successful

2. The optimum condition for forming load occurred at rotation speed at $150 \mathrm{rpm}$, axial feed $0.3 \mathrm{~mm} / \mathrm{rev}$ and burnishing load $25 \mathrm{KN}$.

\section{Acknowledgement}

The authors would like to thank Minia University particularly Production Engineering and Mechanical Design Department for their help and support.

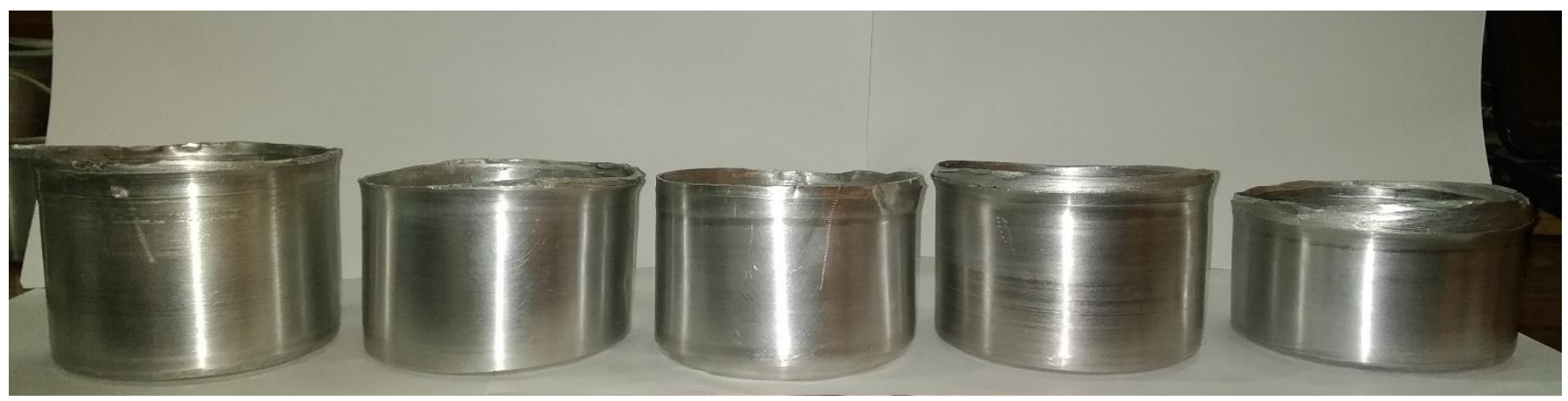

Fig.11. Photograph of successful products.

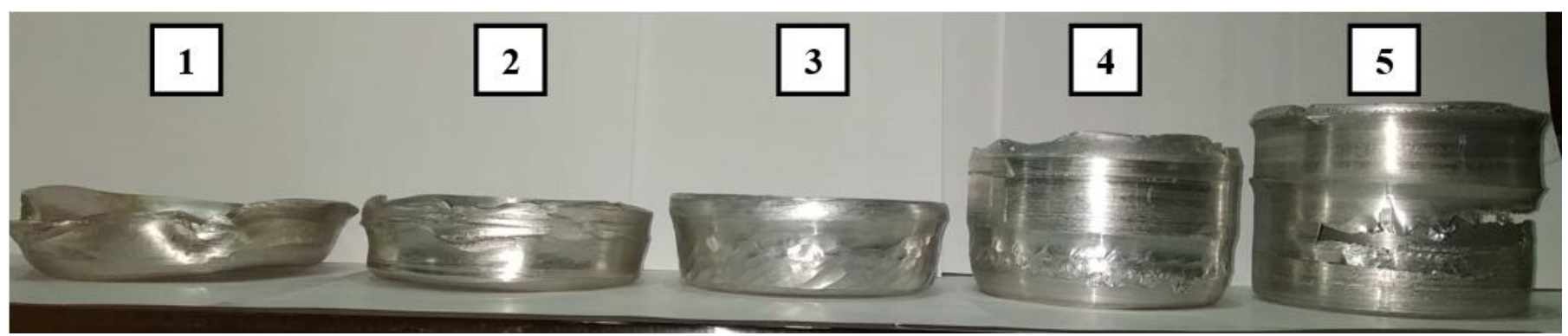

Fig.12. Photograph for Unsuccessful products. 


\section{REFERENCES}

[1] Hosford, W.F. and R.M. Caddell, Metal forming: mechanics and metallurgy. 2011: Cambridge University Press.

[2] Groover, M.P., Fundamentals of modern manufacturing: materials processes, and systems. 2007: John Wiley \& Sons.

[3] Gagov, V., et al., About the sheet metal testing by hydraulic bulging. International Journal of Microstructure and Materials Properties, 2009. 4(5-6): p. 640-648.

[4] Music, O., J. Allwood, and K. Kawai, A review of the mechanics of metal spinning. Journal of materials processing technology, 2010. 210(1): p. 3-23.

[5] Hagan, E. and J. Jeswiet, A review of conventional and modern single-point sheet metal forming methods. Proceedings of the Institution of Mechanical Engineers, Part B: Journal of Engineering Manufacture, 2003. 217(2): p. 213-225.

[6] Brown, J., Advanced machining technology handbook, 1998. McGraw-Hill, New York.

[7] Runge, M., Spinning and flow forming. Leifeld $\mathrm{GmbH} \quad$ Werkzeugmaschinenbau/Verlag Moderne Industrie AG, D-86895, Landsberg/Lech, 1994.

[8] Alberti, N., et al., Analysis of metal spinning processes by the Adina code. Computers \& Structures, 1989. 32(3-4): p. 517-525.

[9] Sagbas, A., Analysis and optimization of surface roughness in the ball burnishing process using response surface methodology and desirabilty function. Advances in Engineering Software, 2011. 42(11): p. 992-998.

[10] Thorat, S. and A. Thakur, Optimization of Burnishing Parameters by Taguchi Based GRA Method of AA 6061 Aluminum Alloy. Materials Today: Proceedings, 2018. 5(2): p. 7394-7403.

[11] Dwivedi, S.P., S. Sharma, and R.K. Mishra, RETRACTED ARTICLE: Effects of roller burnishing process parameters on surface roughness of $\mathrm{A} 356 / 5 \% \mathrm{SiC}$ composite using response surface methodology. Advances in Manufacturing, 2014. 2(4): p. 303-317.

[12] Mahajan, D. and R. Tajane, A review on ball burnishing process. International Journal of Scientific and Research Publications, 2013. 3(4): p. 1-8.

[13] Gomez-Gras, G., et al., Experimental study of lateral pass width in conventional and vibrations-assisted ball burnishing. The International Journal of Advanced
Manufacturing Technology, 2016. 87(1-4): p. 363-371.

[14] Travieso-Rodríguez, J.A., et al., Hardening effect and fatigue behavior enhancement through ball burnishing on AISI 1038. Journal of Materials Research and Technology, 2019. 8(6): p. 5639-5646.

[15] Xia, Q., et al., A study of the one-path deep drawing spinning of cups. Journal of Materials Processing Technology, 2005. 159(3): p. 397-400.

[16] Özer, A., A. Sekiguchi, and H. Arai, Experimental implementation and analysis of robotic metal spinning with enhanced trajectory tracking algorithms. Robotics and ComputerIntegrated Manufacturing, 2012. 28(4): p. 539550.

[17] Kalpakjian, S. and S. Rajagopal, Spinning of tubes: a review. Journal of applied metalworking, 1982. 2(3): p. 211-223.

[18] Switzner, N. and D. Henry, Spin-forming Project Report. 2009, Kansas City Plant (KCP), Kansas City, MO.

[19] Chen, M.-D., R.-Q. Hsu, and K.-H. Fuh, Effects of over-roll thickness on cone surface roughness in shear spinning. Journal of materials processing technology, 2005. 159(1): p. $1-8$.

[20] Molladavoudi, H.R. and F. Djavanroodi, Experimental study of thickness reduction effects on mechanical properties and spinning accuracy of aluminum 7075-O, during flow forming. The International Journal of Advanced Manufacturing Technology, 2011. 52(9-12): p. 949-957.

[21] El-Tayeb, N., K. Low, and P. Brevern, Influence of roller burnishing contact width and burnishing orientation on surface quality and tribological behaviour of Aluminium 6061. Journal of materials processing technology, 2007. 186(1-3): p. 272-278.

[22] Abd-Eltwab, A.A., et al., An investigation into forming internally-spline sleeves by ball spinning. International Journal of Mechanical Sciences, 2017. 134: p. 399-410.

[23] Saied, E.K., et al., Combining conventional spinning with wall thickness reduction in one pass. International Journal of Mechanical and Production Engineering Research and Development, 2019. 9(3): p. 1429-1436. 


\section{دراسة لعملية الرحو التقليدى المركبة مع عملية ترقيق الجدار وعملية الصقل فى وقت واحد}

الملخص العربى

عملية الرحو هي عبارة عن تقنية لتشكيل الصفائح المعدنية المستخدمة في إنتاج الأجزاء الصناعية المتماثلة. الرحو عملية تصنيع فعالة وغير مكلفة وقد استخدت على نطاق واسع في مختلف التطبيقات.

في هذا البحث ، تم تطوير تقنية جديدة لأداء ثلاث عمليات مختلفة في نفس المشوار، وهي الرحو التقليدي والرحو القصي (تقليل سماكة الجدار) وعملية الصقل. تم تتفيذ هذه التقنية الجديدة بواسطة أداة جديدة تتكون من ثلاث مراحل ، المرحلة الأولى تتكون من بكرتين لتنفيذ عملية الرحو التقليدي ؛ المرحلة الثانية تتضمن كرتين متقابلتين للقيام بعملية الرحو القصي والمرحلة الأخيرة تضم كرتين متقابلتين أخريين لتنفيذ عملية الصقل. تختلف كرات الصقل عن كرات القص بانها تحتوي علي سوسته خلف كراتهما وذلك لتحديد حمل الصقل المطلوب.

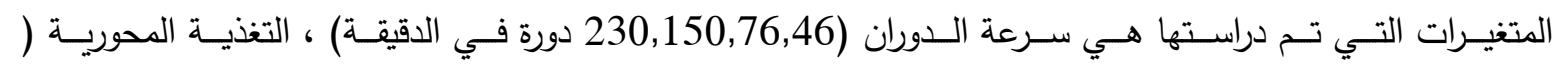

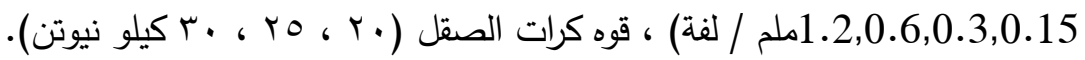
أظهرت النتائج أن الحالة المثلى للقوه الازمه للتشكيل حدثت عند سرعة الدوران عند ،10 دورة في الدقيقة ، والتغذية المحورية ז.. لفة / مم وحمل الصقل بمقدار OY كيلو نيوتن. راوح تركيز الياف اللب من ا.. ٪ إلى ع.. ٪. 